\title{
Wagar, Fertility and Phallic Stelae: Cushitic Sky-God Belief and the Site of Saint Aw-Barkhadle, Somaliland
}

\author{
Sada Mire
}

Published online: 22 March 2015

(C) The Author(s) 2015. This article is published with open access at Springerlink.com

\begin{abstract}
This article is the first to present a study on the wagar, a sacred wooden sculpture kept by Somali women. This study explores the wagar and its significance as a sacred medium within fertility rituals and the religious syncretism in which such indigenous and non/pre-Islamic practice is appropriated and applied for reproduction purposes. The wagar seems to denote a Cushitic symbol of belief in sacred trees within Somali society. The article further explores the potential link between the wagar and the Sky-God Waaq, adhered to by the Cushitic people of the Horn both before and during the practice of Christianity and Islam. The author suggests that the religious centre of Saint Aw-Barkhadle, located in the twelfth-century Islamic ruined townwhich was a major pre-Islamic ritual and burial site according to recent archaeological work - may be linked with the practices of the pre-Islamic religion of Waaq. The article suggests the wagar and phallic gravestones discovered at Aw-Barkhadle and in other parts of the Horn of Africa may be part of Sky-God belief, with an ideology rooted in fertility. Along with traditional archaeological methods, the article also uses the knowledge-centred approach, taking into account local knowledge, oral history and folklore to explore this region's past. The study of the wagar and the shrine of AwBarkhadle contributes to the archaeology of religion and to historical archaeology in the Horn of Africa.
\end{abstract}

Résumé Cet article constitue la première étude sur le 'Wagar', une sculpture sur bois sacré gardée par les femmes somaliennes. Cette recherche étudie le Wagar et sa signification en tant que véhicule sacré dans les rites de fécondité ainsi que le syncrétisme religieux dans lequel une pratique indigène et non/préislamique est opportune et appliquée à des fins de reproduction. Le Wagar semble désigner un symbole couchitique de croyances aux arbres sacrés au sein de la société somalienne. Ainsi, cet article explore le lien potentiel entre le Wagar et le couchitique Dieu du Ciel - appelé Waaq, obéis par les gens de la Corne avant et après le Christianisme et l'Islam. L'auteur suggère que le centre religieux de Saint Aw-Barkhadle, situé dans la ville en ruine du douzième siècle, soit attaché aux pratiques des religions préislamique du Waaq, le Dieu

S. Mire ( $\square)$

ERC Researcher, Faculty of Archaeology, Leiden University, Leiden, Netherlands

e-mail: s.mire@arch.leidenuniv.nl 
du Ciel. Le Wagar peut être une idole de la croyance au Waaq. L'article suggère que le Wagar ainsi que les marqueurs de tombes phalliques découverts à Aw-Barkhadle et à d'autres endroits de la Corne de l'Afrique semblent faire partie de la croyance au Dieu du Ciel et une idéologie de la fertilité. Parallèlement aux méthodes archéologiques traditionnelles, l'article utilise également l'approche centrée sur le savoir qui prend en compte les connaissances locales, l'histoire orale et le folklore pour explorer le passé de cette région. L'étude du Wagar et le sanctuaire de Aw-Barkhadle situé dans la ville du douzième siècle en ruine du même nom, contribue à l'archéologie de la religion et à l'archéologie historique de la Corne de l'Afrique

Keywords Somali · Anthropology and archaeology of religion - Wagar - Sky-God Waaq · Syncretism $\cdot$ Aw-Barkhadle $\cdot$ Fertility $\cdot$ Phallic gravestones $\cdot$ Shrines

\section{Introduction}

One wonders what Picasso might have produced had he encountered and engaged with the wagar (Fig. 1) to the same extent that he did with West African sculpture. Very few people have, in fact, been exposed to Somali material art outside Somali territory. Here I introduce the wagar, a symbol of fertility and part of a wider aesthetic of reproduction within Somali female society, both in the past and present. The wagar is made from a sacred tree considered to possess divine power. Cults of fecundity are found all over the Horn of Africa; I suggest that the wagar is rooted in a pre-Islamic fertility cult that has persisted in a Muslim society. The wagar and its rituals are associated with the preIslamic religion of the Aw-Barkhadle shrine, part of what I consider a sacred landscape - that is to say, an area used solely for ritual purposes, having natural and cultural features that possess ritual meaning, and seen in the local context as "sacred" due to its religious resonance. I also use the term to convey a sense of its ongoing, active use.

Female fertility rituals and use of the archaeological landscape testify to the syncretisation of pre-Islamic and Islamic spiritualities, as will be shown by the integration of Christian elements as well as traditionalist pre-Islamic elements; these include phallic gravestones incorporated into Islamic burials and the ritual landscape in which they are situated. As such, fertility rituals are significant for understanding and interpreting archaeological landscapes, including the shrine of Aw-Barkhadle, believed to predate the ruined town of that name dated to the thirteenth century. In this way, material and ritual data contribute to the archaeology of religion and to historical

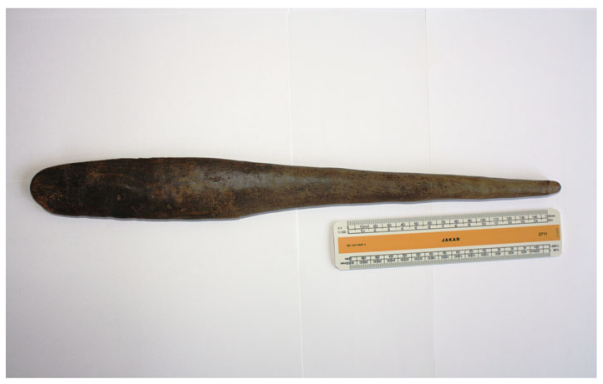

Fig. 1 The wagar of the author's family, 2013. (Photo: by author) 
archaeology in the Horn of Africa. The archaeology of religion has been discussed widely for the African continent and elsewhere (e.g., Insoll 2003, 2004, 2011; Dawson 2009; Steadman 2009).

In recent times, the wagar tradition has been practised in a highly secretive way, not only because of the taboo nature of infertility but also due to the influence of Arabian Salafi Islam, which is violently opposed to "pagan" or "infidel" practices. As a result, the use of the wagar in rituals today seems to be restricted to people in parts of northern Somalia, including internationally unrecognised Somaliland.

Somali verbal art is often more accessible than Somali artefacts. This is due partly to the region's strong oral traditions and partly also to the displacement Somali people have suffered over the last two decades of civil war. In this displacement, people often have had to leave behind most of their material possessions. As most of the Somali have lived and/or still live a nomadic or seminomadic lifeway, they learn from a young age the significance of skills in making essential material culture (Mire 2007, 2011).

In this fashion, knowledge of the skills for making objects is preserved and curated orally. This pragmatic approach to the preservation of heritage stems from nomadism itself, which encourages carrying fewer objects, and praises skills that can be utilised to make objects when needed. The entire landscape thus has a fundamental role in sustaining all that it means to be a thriving human being, socially, culturally and intellectually. For nomads, it seems, this landscape is "home," rather than their identifying closely with a specific structure at a fixed point on the ground. This is why Somalis talk about the landscapes in which they grew up, and the things they learned from their parents and grandparents, as the centrepiece of their cultural heritage rather than objects or monuments. These experiences, oral histories and memories are the heritage they carry wherever they go. I have called this the knowledge-centred approach to heritage (Mire 2007, 2011). It facilitates the transmission process of both tangible and intangible knowledge through time and space, and from generation to generation. This approach has begun to gain acceptance (e.g., Aygen 2013; Linde and Dries et al. 2012; Posnansky 2013). Other scholars have considered and endorsed its potential in viewing archaeology and heritage as something beyond objects and monuments, and in fact connected to communities through experiences, skills, stories, tradition, memories and folklore.

Very little is known about Somali material art and culture in broader contexts, and Somali artefacts have been absent from exhibitions for decades. It has been many years since the "Somalia in Word and Image" exhibition, the catalogue of which was edited by Loughran (1986), and longer still since the appearance of Arnoldi's (1984) "The Artistic Heritage of Somalia" article based on museum collections. The ongoing civil war has also led to the systematic looting and dislocation of Somali artefacts. All national and local museums have been looted (Mire 2007).

Even in the museums of former colonial powers (Britain and Italy), Somali collections including archaeological material sit in storage rooms as they have for more than a century, when most were first assembled. The storage rooms are located often in remote facilities far from the Western metropolitan museums to which the collections belong. There is little documentation for these collections, accompanied as the latter often are merely with notes saying, for example, "a spear from Italian Somaliland/British Somaliland." 
I have not seen a wagar in the collections encountered so far. It should not come as a surprise, then, that this article is the first study of this sacred, secret sculpture (Figs. 1 and 2). The Somali wagar tree is the African olive (Olea europaea sp. africana) (Miskell 2000 on IUCN; USDA). The wild olive is endemic to Somalia, growing on mountain slopes and in woodlands, often near water. Over the last 7 years in Somaliland, I have located the wagar tree at some of the highest points of the Somali plateau: in the Sanaag region at the mountains of Daalo and Jilib Rihin (Fig. 3), in the mountain chain of Dhameer Gowrac near Laaso, and in Garbo Diir in the Togdheer region. These forests of wagar do not seem to have been planted; the tree grows naturally. A number of rock art sites happen to be in these mountain chains, such as Jilib Rihin and Haadh (Mire 2008). The symbolic rock art, along with the many ancient burials (dolmens and cairns) dotting the peaks, suggests that these mountain chains with wagar forests may have been places of past ritual activity.

In Somali society, the entire wagar tree is considered to be blessed and sacred (geed amran), and every part from root to leaves can be used for fighting illness and malevolent activities. It is not clear, however, if the wagar has medicinal qualities from an ethno-botanical perspective beyond its perceived sacredness (amran).

To my knowledge, the wagar is the only wooden, carved object or sculpture that the people of northern Somalia unequivocally consider sacred. Women keep a wagar to become pregnant and protect their fertility, as well as to shield their potential offspring from harm. This is the primary role of the wagar in Somali society today. Women consider it to be an old tradition. It came to my attention as I grew up with it in Somalia, learning about it through my late maternal grandmother, who had inherited her own maternal grandmother's wagar (Fig. 1). She kept this wagar to protect the generations of children she raised or helped raise. Eventually, I inherited this same wagar, believed to be at least a hundred years old. Its black colour is due to its age, as the wood gets darker with the passage of time; the actual colour of the wood is yellow-brown or brown (Fig. 2).

\section{The Production of the Wagar and Other Ritual Wooden Objects}

There are specialised male carvers in different regions of Somalia. The aesthetic value of the wagar seems to be of importance within the interplay of men's creativity and women's aesthetic pleasure. As such, the wagar can be made in different sizes to conform to personal preferences. Some are beautifully ornamented (Fig. 2) and more elaborate than others.

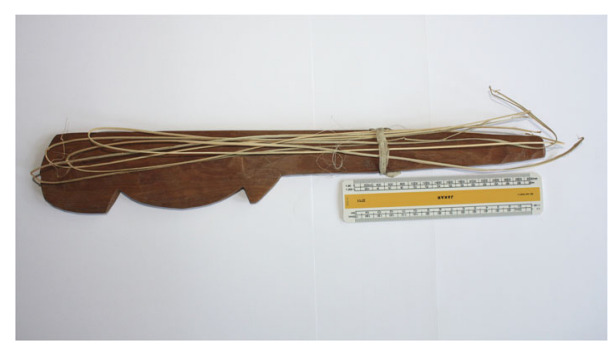

Fig. 2 A wagar bundled with sacred grass, 2013 (Photo: by author) 


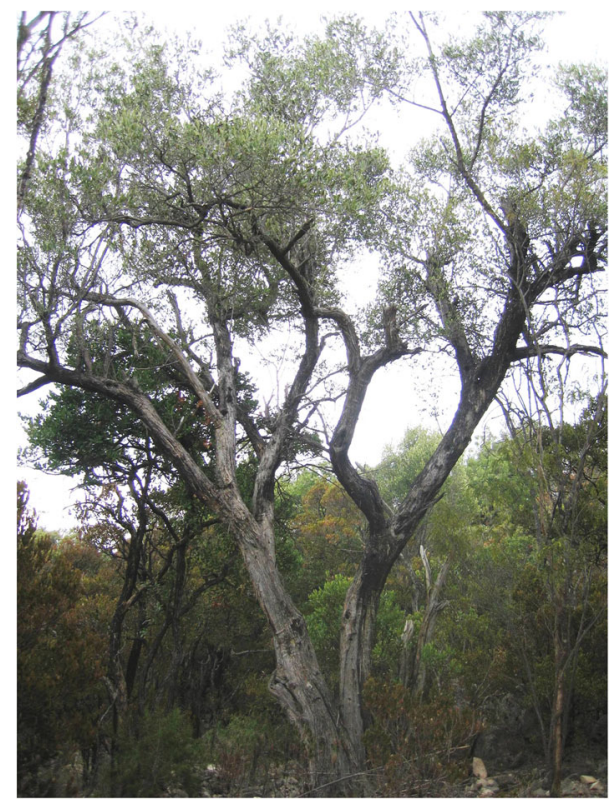

Fig. 3 Wagar, the sacred tree (the African olive), taken at Daallo Mountains, Sanaag region, October 2007 (Photo: by author)

Wood is one of the most significant raw materials in Somali material culture, and wooden objects like the wagar are almost always carved from a single piece of wood. Other wooden art from Somalia includes headrests (barkin), spoons (fandhaal), combs (saqaf or shanlo) and wooden stools (gember or gambadh) (cf. Grottanelli 1986). These, including the ritually important wooden writing planks/blocks or tablets (looh or lawh) used at the Islamic Qur'anic schools, made by men.

In addition, there is an abundance of artefacts made by women, particularly those of nomadic origin ( $c f$. Mire 2006). Among the many objects nomadic women create, it may be worth mentioning here some specifically relating to fertility. The heedho is a ritual vessel used for wedding ceremonies made with fibre from the euphorbia bush in combination with animal skin (saan). Ritual foods may also be kept in the haan, a milk vessel. The protecting basket of the haan may be used as gambis (turned upside down), with a traditional incense burner (dabqaad) made from meerschaum placed under it. The incense permeates the women's clothes hanging over it, and this is believed to purify the person and sanctify the occasion, allowing the woman to receive sacred fertility.

\section{Symbolisms, Associations and Taboos}

Most of the wagar are about 35-45 cm in length. The narrow end measures about $2 \mathrm{~cm}$ in width, and it gets progressively more robust in the middle. The top end is the widest, between 4 and $6 \mathrm{~cm}$. The form of the handle is not entirely round; usually, it is more oval, flattening near the top. The top is either a basic flat shape, or one side might have two bumps (Fig. 2). Sometimes the two bumps are mirrored at the other end as well. 
The wagar itself is thought to be an anthropomorphic representation of a sacred feature or figure, indicating an indigenous non-Islamic religious fertility practice in Somali culture. The bumps appear to be anthropomorphic, perhaps alluding to the distended belly of a pregnant woman. Because of the fact that currently the wagar is associated entirely with women and "underground" fertility rituals, it is said that the wagar symbolises perhaps an ancient religious female figure, a pre-Islamic female deity according to male informants.

In the interpretation of the wagar as a symbol of female power, it is intriguing to note that according to legend, the region of present-day Somalia and Somaliland was ruled by a powerful queen named Araweello. The archaeological cairns common in Somali territory are called araweelloyin, since they are thought to be the graves of this queen's pagan followers in pre-Islamic times. According to the legend, Queen Araweello used to make men perform tricky tasks and enslaved them; this is, people say, because she hated men. She is thought to have had Pharaonic qualities. Finally, her own grandson, who assumed power over the country, killed her. The centrality of womanhood itself, expressed through the veneration of powerful or pious women and goddesses, is an intriguing aspect of fertility cults. However, no female informants have mentioned any ancient female figure in association with the wagar. The women who practise this secretly, currently, perhaps do not want attention and may avoid open links with "pagan" culture. Sociopolitically, in the strongly patriarchal society of the Somali, myths or ideas of strong female figures are not foregrounded. The female figures most revered by the Somali are the first woman (Eve/Haawa) and the first Muslim woman (Fatima, the Prophet's daughter). The Sitaat tradition (Siti or Haawa and Fatima), a ceremony organised by and for women to celebrate female ancestors in the past and the present, is an example of this devotional idiom.

As a result of the legends surrounding the wagar, its links with the issue of sterility, and the rising tide of Salafi influence in Somalia, the Sufi sheikhs who would otherwise openly perform fertility rituals such as rainmaking try to avoid links with the object, as well as all other recently termed "non-Islamic rituals." Salafism opposes belief in the intercession of any spiritual figure but Allah and does not allow the veneration of Sufi saints, as takes place at the Aw-Barkhadle shrine. The destruction of Sufi shrines by local radical Muslim groups in Somalia is ongoing (Mire 2011), paralleling events in Mali and other African countries with Muslim populations. The stigma surrounding sterility itself helps drive these fertility rituals even further underground. The wagar is fast becoming a truly secret practice.

\section{The Fertility Rituals of the Wagar - Gubka (The Burning)}

Different parts of the wagar tree are used to heal women in times of illness, depending on the nature of the malady. The wagar provides fertility through its attributed divine qualities. Barren women are treated with the wagar as a form of healing (dabiib) or medicine (dhaymo). The wagar's pointed tip is heated in oil and then placed on parts of the abdomen, burning particular spots three times. Several locations on the woman's hips are burned, leaving permanent scars. This fertility ritual is called gub (burning) and is important for a woman who wishes to be blessed by the wagar and granted a child. After use, the wagar is kept in a kolay (a private box), usually placed among the 
woman's private possessions. Elderly women keep wagars under their beds, to guard themselves against evil spirits at night.

\section{The Wagar in the Protection of Kinship and Children}

The Somali clan system is patrilineal, and almost every Somali knows who they are by following his or her clan tree, abtirsiimo (the prefix $a b$ denotes descent and bloodlines, and tirsiimo refers to counting). These oral genealogies outline the origin and history of all Somalis. Some argue that the clan trees may extend back to the eleventh century or even further in some cases.

The strong sense of identity Somalis obtained through the clan system is complemented by the culture of nomadism, which imparts a sense of being rooted to a specific kind of lifestyle. As a patriarchal society, there are elements that strengthen the importance of the males for the reproduction of the clan. The protection of the firstborn boy is very important since males are the future inheritors of family wealth and status and may come to hold prestigious titles in the clan.

When a child is born, it must be protected against the pernicious influence of umadaha hoose (evil spirits; lit. "underground beings") and shaydaan or jin (Satan, the devil). The wagar plays an important role in the protection of potential offspring. A period of seclusion takes place in the first 40 days after the birth of a child, during which the mother is not allowed to leave the house unless going to an outdoor toilet, which she may do only when no one can see her. The goal is to protect the woman and the child against malevolent spiritual forces, including the evil eye. It also serves as a preventive measure against infectious illnesses. Traditionally, when the mother must leave the home during her seclusion, she carries the wagar with her, holding it up in front of her as she walks. A wagar is placed near the child, usually under its bed or pillow, to stop an evil spirit from approaching.

In the child protection ritual, various objects are tied to the wagar to add further symbolic meanings and mystical power. One of my informants in Somaliland explained how she carried a wagar and adorned her son with amulets against illnesses and evil spirits so he would have offspring in the future:

My son also had the xildiid and xabasuud [mix of herbs] tied to his arm [an amulet]. Then I gave the qurbaan [the sacrificial offerings to Saint AwBarkhadle]. My boy had headgear made of fat from haydh [stomach fat from sheep and goat]. The hair is removed and the haydh is tied to his head every year [for the veneration of Aw-Barkhadle] till he got married. I have now stopped since he is an adult with children of his own. ("Elderly lady 2" in Hargeysa, 2007)

Alongside haydh, a great many additional materials are required for this ritual. The items are usually made from iron, trees and grass from sacred landscapes. Often, the shrines of Sufi saints in Somalia and Somaliland fall into this category. The aforementioned sacrificial offering was made to the shrine of the twelfth-century Saint AwBarkhadle, a sacred site that will be explored in greater detail below. Such landscapes and items carry multivalent symbolic meanings and suggest the appropriation of preIslamic traditions regarding the sacredness and power of the natural world. The mother 
collects 'aws (grass and palm leaves) from blessed bushes with healing importance and bundles them together with iron objects and a wagar. Some also suggest the use of habaasuud and malmal (herbs and resins). Sharp metal items such as the tooray (dagger), midi (knife), musbaar (screw) and makiinad (razorblade) are attached to the wagar with grass and palm leaves, forming a ritual bundle. The knives, in this context, have further significance with regards to fertility as they are also used for sacrificial slaughter during rainmaking ceremonies. There are records of depictions of knives in the more recent rock art of this region (Grottanelli 1986), which may indicate the relevance of the knife also in the region's archaeology. Iron also shines and the glow is important when "confusing" the evil spirits. Iron has also, it is considered, a magical power and is associated with fertility. The informants (during group interview with "20 women at Laaso," 2007) point out that they also used iron objects to protect the child from evil spirits. Hence, materials such as iron, wood (trees) and grass are linked to the sacred landscape, and its trees and wells. According to legend, Sufi sheikhs including Aw-Barkhadle used iron spears to miraculously create wells. Elsewhere in Africa, the ritual and symbolic significance of iron is recognised in scholarship (e.g., Reid and Maclean 1995; Schmidt and Mapunda 1997). The role of iron in the gender symbolism also has been explored (e.g., Herbert 1993; Schmidt 1998, 1996).

Once assembled, the bundle is then placed under the head of a newborn baby. In my own family, similar arrangements were made for the children using the wagar for protection against evil spirits. The wagar leaves are thought to keep bad spirits out of the house and are hence placed around it. Some children will also wear beads with protective power around the neck and waist. In addition, some parents might acquire amulets containing papers with writings from verses of the Qur'an. However, this practice is not supported by the Ulema (Muslim legal scholars), who argue that the amulets are impious.

The potency of the wagar persists within the Somali Diaspora too. I am aware of many occasions when Somali men have brought a wagar from Somaliland to Sweden and the UK, for example, as a gift to their wives who have given birth, especially if the children were boys. Some highly educated couples enjoy a free and high-quality health care system in countries such as Sweden, yet the wagar remains important for the protection of the children (particularly boys) from evil spirits.

\section{The Wagar as a Sacred Weapon}

The wagar is, as established, from a sacred tree, and for this reason is used as a sacred weapon to fight not only abstract enemies such as umaddaha hoose but also flesh-andblood people. The current belief is that God protects the person carrying a wagar (i.e., this person has God on his/her side, which gives the bearer spiritual superiority and assures victory). The wagar is held in one hand on the level of the person's head in front of the face. In this context, the wagar brings saa iiido (good luck). Both women and men use the wagar to injure someone physically. The fact that the use of the wagar is associated with religious superiority indicates, perhaps, memory of a powerful deity linked with the wagar in older traditions. However, the use of the wagar against evil 
spirits is currently related exclusively to the fertility cult, which is the wagar's main importance within Somali society at the present time.

\title{
The Wagar, Bu'ur Ba'ayr and the Site of Aw-Barkhadle
}

\author{
Merrick Posnansky (2013, p. 48) writes,
}

\begin{abstract}
Unless we are aware of practices in Africa, we are at a disadvantage as we concentrate on the physical manifestations of life such as pots. How did the people we study celebrate the seasons and meaningful passages within life? What would have been the manifestations if any of such commemorations? Shrines, however ephemeral, thus can become as significant as dwelling or activity sites.
\end{abstract}

Women in the northern part of Somalia know about the wagar, its meaning and associated practices. Many people also link it to pre-Islamic times, particularly during the conversion to Islam in northern Somalia between the tenth and thirteenth centuries. Some suggest that the use of the wagar existed perhaps in the pre-Islamic $\mathrm{Bu}$ 'ur $\mathrm{Ba}$ 'ayr era of the Aw-Barkhadle site. The legend of Bu'ur Ba'ayr (Mohamed Hanif) and suspected pre-Islamic practices are deeply linked with the site of Aw-Barkhadle, including the Hill of $\mathrm{Bu}^{\prime} u r \mathrm{Ba}^{\prime}$ ayr. Informants suggest that 850 years ago, an Arabian sheikh, Sharif Yusuf Al-Kawnayn - Saint Aw-Barkhadle - came to the area once known as Dogor but now named after him (Mire forthcoming).

According to the oral history, Aw-Barkhadle has been a centre of Muslim pilgrimage since the twelfth century and is part of a medieval ruined town. Aw-Barkhadle is a 30minute drive from Hargeysa, the capital of Somaliland, and the tomb of this saint has since become the most important pilgrimage centre in Somali territory (Figs. 4 and 5). The ideological and political significance of African shrines has been demonstrated by Dawson (2009), although there is no mention of shrines from the Horn of Africa in Dawson's volume. However, I have found that Aw-Barkhadle has similar political significance. Local people at Aw-Barkhadle attribute the conversion of Somalis to Islam, to the defeat by duel of the previous religious leader, $\mathrm{Bu}^{\text {'ur }} \mathrm{Ba}$ 'ayr, by the Muslim newcomer Aw-Barkhadle. The Saint showed the religious superiority of his beliefs in contrast to the local beliefs of Bu'ur Ba'ayr's followers, whom the former won over in great number.

One of the important potential links between the ritual landscape of Aw-Barkhadle and the wagar is exemplified by an account of an anthropomorphic wooden sculpture used at the tomb of Saint Aw-Barkhadle for female fertility rituals. Women brought a cloth or sling, qayd, to carry the anthropomorphic wooden sculpture while they prayed for fertility in Aw-Barkhadle's tomb. The qayd is used usually to carry a child. In this ritual, the sculpture symbolises the baby the woman longs for. When I asked to see this sculpture at Aw-Barkhadle, I was told that the Qur'an has replaced it in recent years. Now, women carry the Qur'an in the qayd and say special prayers asking for fertility.

Furthermore, the Aw-Barkhadle site is also an ideologically important burial site of the Muslim rulers of Awdal, particularly the Walashma dynasty of the thirteenth and fourteenth centuries AD (Paulitschke 1888). Our team located numerous ruined towns 


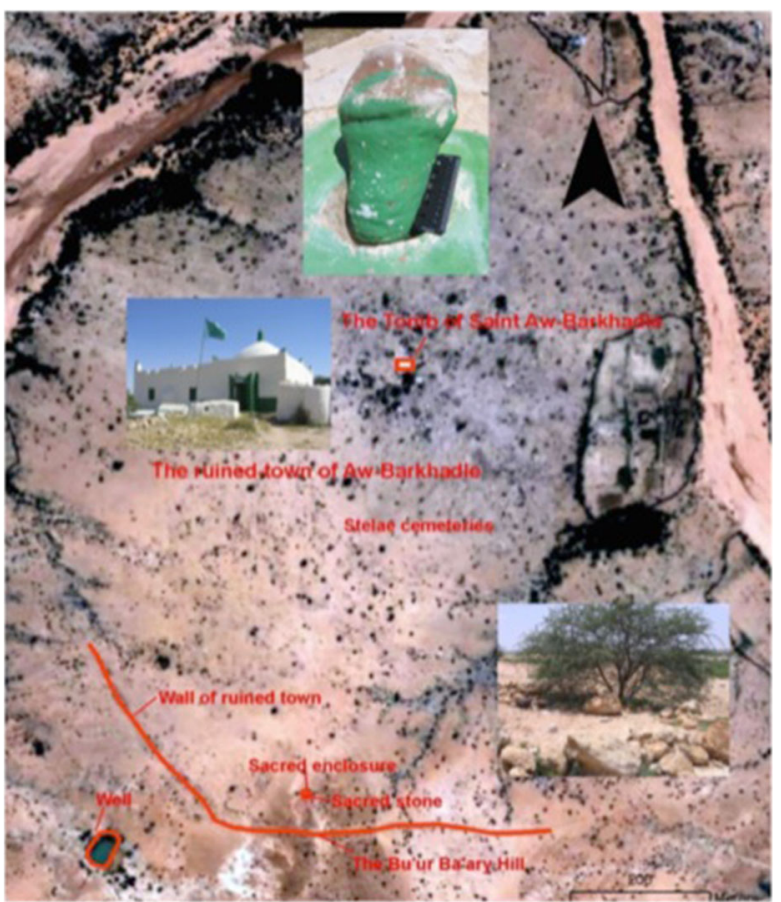

Fig. 4 Plan of the Aw-Barkhadle sacred landscape. Map data: Google and CNES Spot image

dating to the thirteenth century in Somaliland that produced Yuan Dynasty pottery. We also discovered important pre-Islamic heritage at this site in the form of Christian burials, as well as phallic gravestones, dolmens and non-Islamic burial mounds (cairns) attesting to indigenous (Cushitic) beliefs.

The landscape and the ritually significant archaeological features such as tombs, stones (including phallic stones), shrines, and hilltops are all part of the fertility rituals (Mire forthcoming). Those associated with Aw-Barkhadle incorporated, until recently,

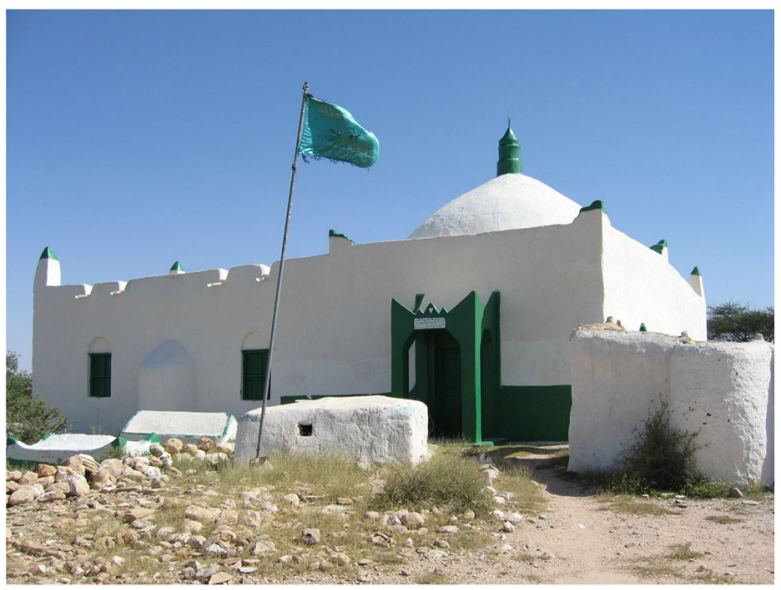

Fig. 5 The Shrine of Saint Aw-Barkhadle, near Hargeisa, Somaliland, September 2007 (Photo: by author) 
Christian elements too. For example, during the annual pilgrimage (ziyara), Muslim

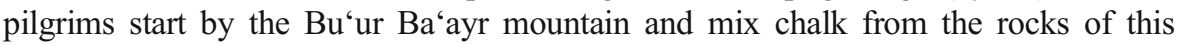
mountain with water from the sacred well; they use the white pigment to paint a Christian cross on their foreheads before proceeding to circumambulate (dawafa) AwBarkhadle's mausoleum. The ziyara is carried out to obtain blessings, including rains and fertility. These syncretic practices were common until recently at Aw-Barkhadle. The link between Christianity and the Aw-Barkhadle archaeological landscape is evidenced by the discovery of gravestones in situ, carved with the Ethiopian Orthodox cross. Not only is the site of Aw-Barkhadle associated with pre-Islamic peoples, but the Christian gravestones and cairns add to the multi-religious significance of the site, a place where people from different religions were buried. Both the preIslamic and Islamic religious figures, and the practices credited to them in terms of rituals in the sacred landscape of Aw-Barkhadle, emphasise fertility and its symbolism.

It would be wise to also note an old Somali saying that refers to the wagar: "wagar iyo ka waasi 'an," which means "even more powerful (audacious) than the wagar and all that." Older generations tend to use it. A mother wishing to chastise a child who comes home late at night may say it to emphasise the child's audacity in going beyond the agreed-upon time. Now the expression is often lost on the younger generations, who may not know what the actual words refer to, much less what a wagar is.

According to one of my interviewees, a local Sufi, "Abdi" (2007), who is locally acknowledged for his interest in history of the Somalis and Sufism,

Wagarku wuxuи kajoogaa sanamadii hore eela caabudijiray berigii jaahilyada, ee Bu'ur Ba'ayr iyo dadkiisii joogay Aw-Barkhadle.

[Wagar is a remnant of the ancient idols that were worshiped in the time of paganism, by $\mathrm{Bu}^{6} \mathrm{ur} \mathrm{Ba}^{6}$ ayr and his people at the site of Aw-Barkhadle.]

According to this, the expression was coined when $\mathrm{Bu}^{\text {'ur }} \mathrm{Ba}$ 'ayr lost his duel with Sheikh Yusuf Aw-Barkhadle. So the rationale goes as follows: If the leader of the people who believed in the wagar was trapped in a mountain by a man with new powers, the new religious power must have been greater than that of the previous leader. The expression, "wagar iyo ka waasi "an" refers to a power greater than that of the wagar: that of Allah. Therefore, in the context of a defiant child, it suggests an even greater audacity on the part of the child in daring to go further than before.

It seems that the wagar was an idol worshipped in this region before the conversion to Islam. Regardless of the current rituals associated with the wagar in Somali female society, it seems to be relevant to the discussion of the site of Aw-Barkhadle, given that some of the informants ("Abdi" 2007; cf. "Elderly lady in Aw-Barkhadle" 2007) suggested a relationship between it and the Aw-Barkhadle sacred landscape.

\section{The Wagar, Waaq and Phallic Symbolism}

According to the legend, $\mathrm{Bu}^{\prime}$ ur $\mathrm{Ba}^{\text {'ayr }}$ married couples by sleeping with the bride during the first six nights of the marriage. I have argued elsewhere (Mire forthcoming) that this likely served to sanctify the marriage and grant a sacred fertility to the new 
union. More such "wicked" and pagan rituals are attributed to Bu'ur Ba'ayr in Somali oral history. However, the finding of phallic stelae (Fig. 6) as well as ancient burial mounds at the site indicates that at least the site was previously used by non-Muslims. Objects similar to the phallic stelae at Aw-Barkhadle are found amongst other eastern Cushitic groups such as the Oromo and the Konso, who have the Sky-God belief and other practices in common. These include the kallascha, a phallic symbol (Hallpike 1972), and the waga statues of the Konso. The phallic element is crucial as this symbol is very common in both the archaeology and ethnography of the Horn, although it has been neither reported nor analysed appropriately. In the Horn of Africa, there are several archaeological sites that have phallic gravestones. The two most well known of these sites are Tutu Fela (Fig. 7) and Tututi in southern Ethiopia (Joussaume 1995). These stelae might be associated with the belief in Waaq. In the Somali context, it is possible that the wagar itself may have been a phallic object. If so, it could explain the ambiguousness of its appearance currently. The significance of legends such as that of Bu'ur Ba'ayr evokes a sacred symbolic intercourse, perhaps involving a sacred man, a notion recalled by the phallic stelae. Thus, the Bu'ur Ba'ayr legend and fertility rituals such as that of the wagar may shed light on the motivation and ritual significance behind, for example, the portable phallic stones. The case of Aw-Barkhadle rituals, the archaeological landscape and associated material culture suggests a widespread fertility ideology which might help explain many intriguing fertility symbols, including the phallic symbolism expressed through stelae and other grave markers in the Horn of Africa.

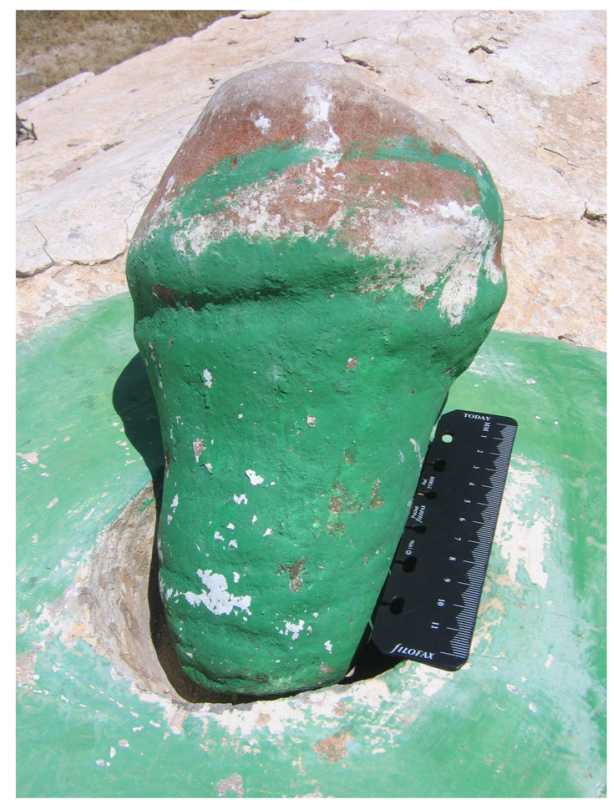

Fig. 6 A phallic stelae resting on its niche atop a Muslim grave at Aw-Barkhadle, September 2007 (Photo: by author) 


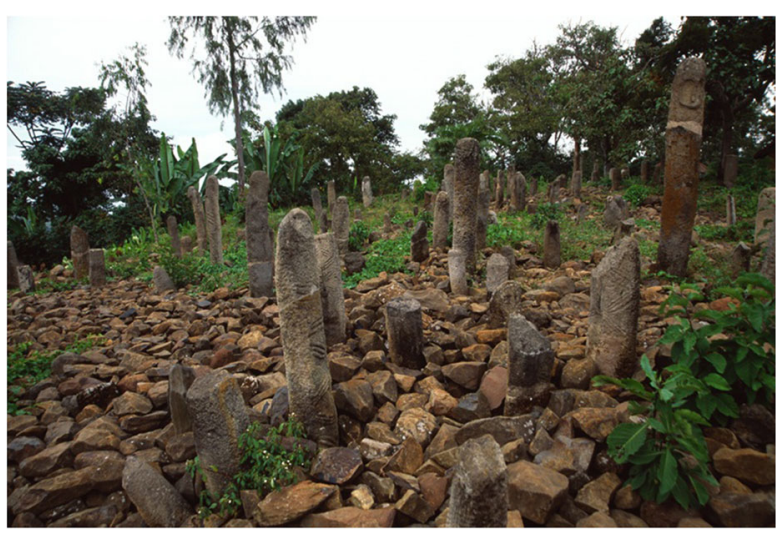

Fig. 7 Tuto Fella phallic stelae cemetery. Copyright: David Coulson/TARA (with permission)

\section{The Wagar, the Man in the Tree, and Waaq the Sky-God}

Waaq belief is the most likely non-Islamic/non-Christian belief which would have been contemporary to or predated Islam, and with which legends such as that of $\mathrm{Bu}^{\text {'ur }}$ $\mathrm{Ba}^{\prime}$ ayr are most likely to have been associated. It is generally accepted to have been part of the Cushitic and pre-Christian/Islamic institutions in this region. Taking into consideration the above observations (the fertility rituals, rituals for accessing sacred fertility, phallic stelae, pre-Islamic mounds, myth of $\mathrm{Bu}^{\text {'ur }} \mathrm{Ba}$ 'ayr and belief in Waaq), these all point to the wagar as part of pre-Islamic repertoire of belief in sacred trees and the Aw-Barkhadle site.

Whether the wagar suggests a man or a woman (or both), one thing is clear; even now, it remains associated with pre-Islamic religious power and belief in sacred trees. It is possible that the wagar itself has changed appearance during Islamic times, perhaps to appear as nonfigurative as possible. This exclusion of certain characters is important because it is what is not uttered or displayed, or expressed visually, that underlies the power of the wagar.

First, it is important to think of the wagar as a mask: the person carrying it is displaying it towards something (evil spirits) and the mask disguises the carrier. It has powers to perform an act, that of transforming relations between the carrier and the potential aggressor for the purposes of protection.

Second, as a mask, the wagar might be a feature of a sacred figure or deity venerated for his or her ritual efficacy in providing fertility within the Somali. In any case, it is at least clear that the wagar transforms or communicates the idea of sacred trees, and as such represents a medium for sacred power or divine fertility.

Lévi-Strauss (1982, p. 144) noted,

... a mask is not primarily what it represents but what it transforms, that is to say, what it chooses not to represent. Like a myth, a mask denies as much as it affirms. It is not made solely of what it says or thinks it is saying, but of what it excludes.

In order to understand what type of deity or power the wagar represents, then, the wider cultural context must be explored. This is crucial for examining the historical 
meaning and uses of the wagar. The word waga/Waĝa (or Waaq) denotes the Sky-God adhered to by many Cushitic people (including the Konso) in the Horn of Africa (Loo 1991; Trimingham 1965), including the Somali in pre-Islamic times. That fact can also be associated with the practices of some Cushitic groups when marking graves. For example, the Konso use wooden sculptures to represent the deceased; these ancestral sculptures are also known as waga (Hallpike 1972). In addition, some Cushitic speaking peoples who today adhere to the Sky-God call him Waĝa rather than Waaq (Bartels 1983; Hallpike 1972; Loo 1991; Trimingham 1965). Although the words wagar and Wagha (Waaq/Waqa) may suggest similarity, a reconstruction of the historical linguistics behind them kindly carried out by Christopher Ehret for the purpose of the current article, suggests no link (C. Ehret, pers. comm. 15/06/2013). Like the Konso, the Somali speak a proto-South Lowland Eastern Cushitic language (Ehret 1995, 2012). Ehret suggests that the words *wagar and *Waak' are distinct old ProtoEastern Cushitic (PEC) roots. *Waak' means "rise up" and this suggests its meaning in the sky and relation to the Sky-God, while the PEC root*wagar simply means "olive" (C. Ehret, pers. com. 15/06/2013).

Belief in the Sky-God may relate to the myth of the man who was sitting in a tree (perhaps a sacred tree, even an olive). This is a common myth of origin told by Cushitic people of the Horn, particularly the Oromo, Afar, Saho and Somali (Luling 1988). According to this myth, a little girl discovered a stranger from the sky, a man, sitting on a tree, who would only agree to come down when he was promised that he could marry the local girl who found him. He was allowed to marry her, and the people emerged from their union. Versions of this myth are widespread in the Horn. It seems to indicate a potential link between the notion of trees and ancestral figures, as also exemplified by Konso waga sculptures. As an example, the wagar is, as noted earlier, carved from the wood of a sacred tree. The sycamore tree is, similarly, venerated by Cushitic peoples (Burton 1966; Trimingham 1965, p. 260; cf. Hallpike 1972). More broadly, it can be said that the worship of trees is extremely important within many Cushitic-speaking societies of the Horn even today, including the Konso and Oromo. Thus, the worship of trees and its potential link with the wagar are relevant to discussions of Sky-God belief. The potential link is the sacred fertility that the wagar is considered to provide. An investigation of the relationship between the idea of sacred trees, the myth of a man in a tree, and the wagar may suggest something of the deeper nature of Waaq.

The Konso believe that the juniper is sacred (Hallpike 1972). The Oromo and the Konso hold that the ayaana (the spirits of destiny) inhabit the sycamore and African olive (wagar), and Oromo traditionalists consult such trees. Perhaps the Sky-God Waaq was thought to inhabit the sacred wagar tree within the Somali tradition. Currently within Somali society, ayaana exist as spirits that are deeply associated with the self. These personal spirits are also called rooxaan and are now associated with local Sufi mysticism.

Among the Oromo, the intermediary between Waaq and the people is a ritual expert, the Qallu, or highest spiritual leader, who is believed to be in constant communication with the deity. The most important custom of the Boorana is gadamoji, the initiation cycle, which lasts 8 years (Adamson 1967). The Ethiopist historian Carlo Conti Rossini (1872-1949), quoted in Trimingham, wrote (1965, pp. 260-261): 
I also observed another extravagant supervision, which we could scarcely expect from Mahomedans [Muslims]. They pay great respect to certain trees. There was a tree in Mersa [in northern Ethiopia] which they particularly hold in great reverence. My people, desiring to sit down under its shadow, were immediately driven away, lest the Adbar should be angry. Adbar means keeper or watchman. They grease this tree, and perform religious ceremonies under it. Nobody dare touch or damage the tree without risking a severe punishment.

Trees are consulted on issues of childbirth, as they are regarded as priests (Loo 1991). Oromo daughters get ceremonial sticks from their fathers when they marry which they keep for the rest of their lives. These sticks are called Siqe (Adamson 1967, p. 271). The stick symbolises the girl's power, and she carries it during the marriage ceremony and in all other rituals thereafter. One of the holy trees of the Oromo is called dampi. There are also sticks that the father gives to his sons in their initiation ceremony.

Waaq worship emphasises peace and harmony within the group, as well as between nature and people. The Cushitic concept for this is nagi (peace/harmony), which is to be maintained at all costs in order for the ancestors to bless the people. What Conti Rossini witnessed showcases Cushitic peoples' commitment to the protection of sacred trees, such as the juniper, the sycamore and the African olive, which they care for and to which they make sacrifices. They do this in order to propitiate the divine powers and provide sacred fertility to the people. Not only is communal prosperity important, but considerable prestige is attributed to individual achievement. Achievements are symbolised, in the case of the Konso, by the erection of waga sculptures at the grave of the diseased representing him, as well as sculptures representing his wife and any enemies or big game he killed during his life.

\section{Conclusions}

This study has explored the wagar and its significance as a sacred medium within fertility rituals. I argue that the wagar denotes a Cushitic (non-Islamic) symbol of worship of sacred trees, past and present. Furthermore, the wagar may be linked with the rituals of the pre-Islamic religion of Waaq, the Sky-God. The wagar might also have served as a symbol of a sacred deity within this belief, perhaps the Sky-God Waaq. The wagar may be linked to the sacred site of Saint Aw-Barkhadle at the twelfth-century Islamic ruined town of the area, previously known as Doggor. Analysis of the wagar and female fertility rituals may contribute to our understanding of the archaeological landscape there. The Sky-God belief seems to indicate a fertility ideology. The wagar, as well as the archaeologically known phallic grave markers discovered at Aw-Barkhadle and in other parts of the Horn of Africa, seem to be part of such an ideology of fertility.

It is beyond the scope of this article to discuss the potential relationship between the symbolisms of materials, rituals, spaces and indigenous religion at Aw-Barkhadle. I explore elsewhere (Mire forthcoming) the potential relationship between sacred stones, the phallic Kallascha of the Konso and Oromo, and archaeological phallic stelae traditions from the Horn of Africa. However, by investigating historical legends of pre-Islamic figures such as $\mathrm{Bu}^{\prime}$ ur $\mathrm{Ba}^{\text {'a } a y r}$ associated with the sacred and ritual landscape 
of Aw-Barkhadle, and by recording/analysing the rituals that continue to take place there, it becomes clear that we are dealing with a material culture associated with particular ritual activities and landscape features. This material culture seems to be linked to a continuous tradition of ascribing ritual significance to fertility in the region in general, and to a belief in Waaq (Waĝa) in particular.

Hence, these triadic data - rituals, sacred landscape and material culture-which relate to one another through female fertility rituals, assist in shedding light on the archaeological landscape and the potentially continuous use of sites of this nature. This article is the first study of the wagar, and more relevant female fertility rituals will be explored elsewhere. There needs to be further research from a holistic perspective such the knowledge-centred approach, which observes how memories, tradition, practice, symbolism and folklore (including proverbs/metaphors) can inform archaeological inquiry, and which combines ethnography, oral traditions, oral and written literature, historical linguistics and archaeology to shed light on aspects of the past, such as an atmosphere of religious syncretism in which such indigenous and non/pre-Christian/ Islamic practices are adopted and used for reproduction purposes up to the present.

Acknowledgments Thanks to the anonymous reviewers for their valuable and constructive comments, and to my friends: Anne Moltes, who kindly translated the abstract into French, and Wendy Coleman and Marilyn Downes, who proofread drafts. I am also grateful for comments from scholars on previous versions of this study: Dr. David N. Edwards, Dr. Charlie Gore, Dr. G.R.D. King, Dr. Andrew Reid and Professor David Wengrow. Special thanks to Dr. Mary Anne Murray, who identified the wood of my grandmother's wagar, and to Professor Christopher Ehret, who reconstructed the linguistic history of the words wagar and Waaq (Waga) for this paper. I also thank all of my informants. I am eternally grateful to my mother and maternal grandmother for introducing me to a part of my heritage I otherwise never would have known. The shortcomings of this article are mine only.

Open Access This article is distributed under the terms of the Creative Commons Attribution License which permits any use, distribution, and reproduction in any medium, provided the original author(s) and the source are credited.

\section{References}

Adamson, J. (1967). The peoples of Kenya. London: Collins \& Harvill Press.

Arnoldi, M. J. (1984). The artistic heritage of Somalia. African Arts, 17(4), 24-33.

Aygen, Z. (2013). International heritage and historic building conservation: Saving the world's past. Routledge Studies in Heritage.

Bartels, L. (1983). Oromo religion: Myths and rites of the western Oromo of Ethiopia: An attempt to understand. Berlin: Dietrich Reimer Verlag.

Burton, R. (1966). First footsteps in East Africa. London: Routledge \& Kegan Paul.

Dawson, A. C. (2009). Shrines in Africa: History, politics and society. Calgary: University of Calgary Press.

Ehret, C. (1995). The Eastern Horn of Africa, 1000 BC to 1400 AD: The historical root. In A. J. Ahmed (Ed.), The invention of Somalia (pp. 233-256). Lawrenceville: Red Sea Press.

Ehret, C. (2012). Linguistic archaeology. African Archaeological Review, 29(2), 109-130.

Grottanelli, V. (1986). Somali wood engravings. In K. S. Loughran (Ed.), Somalia in word and image (pp. 97104). Bloomington: Indiana University Press.

Hallpike, C. R. (1972). The Konso of Ethiopia: A study of the values of a Cushitic people. Oxford: Clarendon Press.

Herbert, E. W. (1993). Iron, gender and power: Rituals of transformation in African societies. Bloomington: Indiana University Press.

Insoll, T. (2003). The archaeology of Islam in sub-Saharan Africa. Cambridge: Cambridge University Press. Insoll, T. (2004). Archaeology, ritual, religion. London: Routledge. 
Insoll, T. (Ed.). (2011). The Oxford handbook of archaeology of ritual and religion. Oxford: Oxford University Press.

Joussaume, R. (Ed.). (1995). Tiya - L'Éthiopie des mégalithes: Du biface à l'art rupestre dans la Corne de l'Afrique. Mémorie XI. Ministère des Affaires Étrangères, Ministère de la Coopération, Ambassade de France en Éthiopie, UNESCO, UPR 311 du CNRS.

Lévi-Strauss, C. (1982). The way of the masks. Seattle: University of Washington Press.

Luling, V. (1988). The man in the tree: A note on a Somali myth. In A. Puglieli (Ed.), Proceedings of the Third International Congress of Somali Studies. II Pensario Scientifico: Rome.

Mire, S. (2006). Gaashaan, Somali shield. In K. Lagat \& J. Hudson (Eds.), Hazina: Trade, transition and transformation (pp. 12-13). The National Museums of Kenya and the British Museum.

Mire, S. (2007). Preserving knowledge, not objects: A Somali perspective for heritage management and archaeological research. African Archaeological Review, 24(3-4), 49-71.

Mire, S. (2008). The discovery of Dhambalin rock art site, Somaliland. African Archaeological Review, 25(34), 153-168.

Mire, S. (2011). The knowledge-centered approach to the Somali cultural emergency and heritage development assistance in Somaliland. In F. Sulas (Special Issue Guest Ed.), Africa's Fragile Heritages. African Archaeological Review, 29(1), 71-91.

Mire, S. (forthcoming). Divine Fertility. Walnut Creek: Left Coast Press.

Miskell, J. (2000). An ecological and resource utilisation assessment of Gacaan Libaax, Somaliland. IUCN Eastern Africa Programme. Somali Natural Resources Management Programme. IUCN the World Conservation Union. www.iucn.org/places/earo/pubs/drylands/SOMALIAR.PDF.

Paulitschke, P. (1888). Beiträge zur ethnographie und anthropologie der Somali, Galla und Harari. Leipzig: Eduard Baldamus.

Posnansky, M. (2013). Present: Past. South Carolina Antiquities, 43, 47-49.

Reid, A., \& Maclean, R. (1995). Symbolism and social contexts of iron production in Karagwe. World Archaeology, 27(1), 144-161.

Schmidt, P. R. (1996). Reconfiguring the Barongo: Reproductive symbolism and reproduction among a work association of iron smelters. In P. R. Schmidt (Ed.), The culture and technology of African iron production (pp. 74-127). Gainesville: University Press of Florida.

Schmidt, P. R. (1998). Reading gender in the ancient iron technology of Africa. In S. Kent (Ed.), Gender in African prehistory (pp. 139-162). Walnut Creek: AltaMira Press.

Schmidt, P. R., \& Mapunda, B. B. (1997). Ideology and the archaeological record in Africa: Interpreting iron symbolism in iron smelting technology. Journal of Anthropological Archaeology, 16(1), 73-102.

Steadman, S. (2009). Archaeology of religion. Walnut Creek: Left Coast Press.

Trimingham, J. S. (1965). Islam in East Africa. Oxford: Clarendon Press.

USDA National Resources Conservation Service. Plants profile. http://plants.usda.gov/cgi_biin/plant profile. cgi?earl=plant_profile.cgi\&symbol=OLEUA. Accessed 22 March 2005.

van de Loo, J. (1991). Guji Oromo culture in southern Ethiopian Religious capabilities in rituals and songs, with collaboration of B. Kola. Berlin: Deitrich Reimer Verlag.

van der Linde, S. J., \& van der Dries, M. H. (2012). Preserving knowledge as a basic human need: On the history of European archaeological practices and the future of Somali archaeology. An interview with Sada Mire. In S. J. van der Linde, M. H. van der Dries, N. Schlanger, \& C. G. Slappendel (Eds.), European archaeology abroad: Global settings, comparative perspectives (pp. 375-386). Leiden: Sidestone Press. 